\title{
PHARMACEUTICAL STANDARDIZATION OF PANCHAGUNA TAILA (MEDICATED OIL) AND PRODUCT DEVELOPMENT AS OINTMENT, GEL, CREAM, AND PHYSIOWAX
}

\author{
SWETA KUMARI, DILEEP SINGH BAGHEL* \\ Department of Ayurvedic Pharmacy, School of Pharmaceutical Sciences, Lovely Professional University, Punjab - 144411, India. \\ Email: baghel_12@rediffmail.com
}

Received: 14 July 2017, Revised and Accepted: 25 July 2017

\begin{abstract}
Objective: The present study aimed to prepare Panchaguna taila (PGT) and its development in various dosage forms, i.e. ointment, gel, cream, and physiowax to exemplify the characteristic parameters according to pharmaceutical standards.

Methods: PGT is polyherbal medicated oil used externally for treating wounds, cut, and burn and used for massaging in rheumatoid arthritis, muscular pain, sprains, and joints pain. Prepare the decoction using Haritaki, Vibhitaki, Amalaki, Nimba, Sambhalu and prepare paste (kalka) from Madhuchishta, Gandhaphiroja, Shilarasa, Rala, and Guggulu. Mix all the ingredients and heat till watery portion not evaporated from the oil with constant stirring then filter it. Add eucalyptus oil, turpentine oil, and kejoputi oil at the end and stir it well. Prepare various dosage forms like ointment, gel, cream, and physiowax using suitable base for the better and improved therapeutic application. Analytical standards for PGT such as acid value, saponification value, iodine value, and peroxide value were performed, and obtained results were appeared under the prescribed limit of the official monograph. Various physicochemical parameters such as homogeneity, spreadability, pH, and melting point were performed for PGT ointment, PGT gel, PGT cream, and PGT physiowax. Stability study of PGT was done for 3 days under the accelerated conditions.
\end{abstract}

Results: In PGT, various physicochemical parameters were performed on the interval of 24, 48, and 72 hrs, and no significant variation found in their physicochemical properties when observed values were compared. PGT ointment, PGT gel, PGT cream, and PGT physiowax containing PGT as active pharmaceutical ingredient with various suitable excipients and base are easy to formulate and convenient to apply over the affected area. Rf observed between the ranges 0.21 to 0.84 as given in the standard monograph. In PGT, PGT ointment and PGT physiowax, 10 spots were found, and in PGT gel and PGT cream, 7 spots were found. $0.11,0.15$, and 0.34 spots were found in the PGT gel, PGT cream, and PGT physiowax, respectively, that can be given by the excipients or base used for their preparation.

Conclusion: It is possible to make other dosage form of PGT which can be more convenient to the customers. Hence, the issues related to the PGT like staining and sticking can be resolved by developing or converting the PGT into various convenient dosages.

Keywords: Panchaguna taila, Sneha kalpana, Ointment, Gel, Cream, Physiowax.

(C) 2017 The Authors. Published by Innovare Academic Sciences Pvt Ltd. This is an open access article under the CCBYlicense (http://creativecommons org/licenses/by/4. 0/) DOI: http://dx.doi.org/10.22159/ajpcr.2017.v10s4.21337

\section{INTRODUCTION}

Sneha kalpana provides an idea that Sneha kalpas are superior to other dosage forms due to its advantages such as increased absorption, bioavailability, and extraction of fat soluble as well as a water soluble active principle at a time in a single formulation [1]. Panchaguna taila (PGT) is polyherbal medicated taila used externally for treating wound, cut, burn, and earache and used for massaging in rheumatoid arthritis, muscular pain, and joint pain. [2]. PGT form is beneficial; it poses certain inconveniences while application, handling packaging, and transportation. The big hurdle is its sticky nature, and when applied over the skin, it leaves stain on the applied area and the cloth. Thus, this creates the need to better and improved therapeutic application as various dosage forms of PGT. Hence, an attempt has been made to develop the new dosage form of PGT as ointment, gel, cream, and physiowax on trial and error basis for better acceptability and compliance. Further attempts were made to evaluate preliminary phytochemical and physiochemical profile of the PGT and its conventional prepared dosage forms.

\section{MATERIALS AND METHODS}

Procurement of raw material/collection of raw material and authentication of raw material

All the raw materials required for the project purchased from the local market of Jalandhar. Sambhalu leaves (Nirgundi) and Neem leaves were collected from the herbal garden of the Lovely Professional University.
Authentication of all the raw material is carried out by Dr. Satiwinderjeet Kaur, Head, Department of Botanical and Environmental Sciences, Guru Nanak Dev University Amritsar, Punjab, with Ref. No. 1087, Date $18 / 10 / 16$

\section{Preparation of PGT}

Before formulating, PGT Guggulu was purified [3,4] and Taila murchana [5] was done. PGT was prepared according to the procedure mentioned in the Ayurvedic Pharmacopoeia of India Part II; Volume III [2]. Master formula for PGT is mentioned in Table 1.

\section{Preparation of ointment}

PGT ointment was prepared using PGT as API and white paraffin wax as base, and the composition given in Table 2 [6-9].

\section{Preparation of gel}

PGT gel master formula for different batches prepared is given in Table 2. PGT of required quantity was taken in a mortar, added with thickening agents given in specified proportion. The contents were homogenized using stirrer. Stirring was continued till desired consistency of product was obtained and stored in airtight container [10].

\section{Preparation of cream}

PGT cream was prepared using PGT as API, and the master formula for the batches prepared is given in Table $2[7,10]$. 
Preparation of physiowax

PGT and white paraffin wax required quantity was taken in a beaker and heat over a water bath at $60^{\circ} \mathrm{C}$ and then transferred it to the mortar. The contents were homogenized by the action of stirrer. Stirring was continued till desired consistency of product was obtained and stored in airtight container. PGT cream master formula for the batch is given in Table 2.

\section{Characterization of PGT and its dosage forms} Analytical study

The raw materials and formulations were first analyzed for organoleptic parameters like color, odor, taste, texture, etc., as shown in Table 3.
The formulations were analyzed for the presence of various chemical constituents like alkaloids, glycoside, tannin, phytoterols, etc., [11,12]. Physicochemical analysis includes acid value, iodine value, saponification value, peroxide value, $\mathrm{pH}$, and spreadability. Analysis of samples was performed as per the API standards and PLIM (Pharmacopoeial Laboratory of Indian Medicine) protocol as shown in Tables 4-6 [2, 13-15].

\section{Thin-layer chromatography (TLC) study}

Shook the $1 \mathrm{ml}$ of sample with $10 \mathrm{ml}$ of Toluene and kept the mixture for 12 hrs. Filtered the extract and carried out TLC [2].

- Mobile phase - Toluene, ethyl acetate, methanol, and glacial acetic acid (8.5:0.5:0.2: 0.1).

Table 1: Master formula for PGT [16]

\begin{tabular}{lllll}
\hline S. No. & Raw drug & Part used & Quantity (AFI) & Quantity taken \\
\hline 1. & Haritaki & Fruit pulp & $60 \mathrm{~g}$ & $110 \mathrm{~g}$ \\
2. & Amalaki & Fruit pulp & $60 \mathrm{~g}$ & $110 \mathrm{~g}$ \\
3. & Bibhitaki & Fruit pulp & $60 \mathrm{~g}$ & $110 \mathrm{~g}$ \\
4. & Nimba patra & Leaves & $180 \mathrm{~g}$ & $330 \mathrm{~g}$ \\
5. & Sambhalu patra & Leaves & $180 \mathrm{~g}$ & $330 \mathrm{~g}$ \\
6. & Jala reduced to & - & $4,320 \mathrm{ml}$ & $7,920 \mathrm{ml}$ \\
& & & $1,080 \mathrm{ml}$ & $1,980 \mathrm{ml}$ \\
7. & Tila taila & Oil & $960 \mathrm{ml}$ lained & $860 \mathrm{ml}$ \\
8. & Madhucchistha (Mom) & - & $48 \mathrm{~g}$ & $88 \mathrm{~g}$ \\
9. & Gandhaviroja (Saral) & Resin & $48 \mathrm{~g}$ & $88 \mathrm{~g}$ \\
10. & Sila rasa (Turusk) & Exudate & $48 \mathrm{~g}$ & $88 \mathrm{~g}$ \\
11. & Raal & Exudate & $48 \mathrm{~g}$ & $88 \mathrm{~g}$ \\
12. & Guggulu (Suddha) & Exudate & $48 \mathrm{~g}$ & $110 \mathrm{~g}$ \\
13. & Karpura & - & $60 \mathrm{~g}$ & $55 \mathrm{ml}$ \\
14. & Tarpina taila & Oil & $30 \mathrm{ml}$ & $55 \mathrm{ml}$ \\
15. & Eucalyptus taila & Oil & $30 \mathrm{ml}$ & $55 \mathrm{ml}$ \\
16. & Cajuputi taila & Oil & $30 \mathrm{ml}$ & \\
\hline
\end{tabular}

AFI: Ayurvedic formulary of india

Table 2: Formulas for various batches of PGT dosage forms

\begin{tabular}{|c|c|c|c|c|c|c|c|c|c|c|c|c|}
\hline \multirow[t]{2}{*}{ Chemical name } & \multicolumn{3}{|c|}{$\begin{array}{l}\text { Ointment (quantity) } \\
\text { Batch }\end{array}$} & \multicolumn{3}{|c|}{$\begin{array}{l}\text { Gel (quantity) } \\
\text { Batch }\end{array}$} & \multicolumn{3}{|c|}{$\begin{array}{l}\text { Cream (quantity) } \\
\text { Batch }\end{array}$} & \multicolumn{3}{|c|}{$\begin{array}{l}\text { Physiowax (quantity) } \\
\text { Batch }\end{array}$} \\
\hline & I & II & III & I & II & III & I & II & III & I & II & III \\
\hline White paraffin wax & $5 \mathrm{~g}$ & $10 \mathrm{~g}$ & $2 \mathrm{~g}$ & - & - & - & - & - & - & $3 g$ & $4 \mathrm{~g}$ & $5 g$ \\
\hline Emulsifying wax & - & - & $1.2 \mathrm{~g}$ & - & - & - & $1 \mathrm{~g}$ & $1 \mathrm{~g}$ & $1 \mathrm{~g}$ & - & - & - \\
\hline Liquid paraffin & - & - & $1 \mathrm{ml}$ & - & - & - & $0.6 \mathrm{ml}$ & $0.6 \mathrm{ml}$ & $0.6 \mathrm{ml}$ & - & - & - \\
\hline Methylparaben & - & - & $0.01 \mathrm{~g}$ & - & - & - & $0.01 \mathrm{~g}$ & $0.01 \mathrm{~g}$ & $0.01 \mathrm{~g}$ & - & - & - \\
\hline Propylparaben & - & - & $0.01 \mathrm{~g}$ & - & - & - & $0.01 \mathrm{~g}$ & $0.01 \mathrm{~g}$ & $0.01 \mathrm{~g}$ & - & - & - \\
\hline Water & - & - & $3.2 \mathrm{ml}$ & - & - & - & $4.2 \mathrm{ml}$ & $4.2 \mathrm{ml}$ & $4.2 \mathrm{ml}$ & - & - & - \\
\hline Carbopol934 & - & - & - & $1.5 \mathrm{~g}$ & $1.5 \mathrm{~g}$ & - & $0.02 \mathrm{~g}$ & $0.02 \mathrm{~g}$ & $0.02 \mathrm{~g}$ & - & - & - \\
\hline Vitamin E & - & - & - & - & - & - & - & - & - & - & - & - \\
\hline Aerosil & - & - & - & - & - & $0.6 \mathrm{ml}$ & - & - & - & - & - & - \\
\hline Glycerine & - & - & - & - & - & - & $1 \mathrm{ml}$ & $1 \mathrm{ml}$ & $1 \mathrm{ml}$ & - & - & - \\
\hline Propylene glycol & - & - & - & - & - & - & - & - & - & - & - & - \\
\hline Ethanol & - & - & - & - & $5 \mathrm{ml}$ & - & - & - & - & - & - & - \\
\hline TEA & - & - & - & - & - & - & $0.02 \mathrm{ml}$ & $0.02 \mathrm{ml}$ & $0.02 \mathrm{ml}$ & - & - & - \\
\hline
\end{tabular}

PGT: Panchaguna taila, TEA: Triethanolamine

Table 3: Preliminary analysis of formulations

\begin{tabular}{|c|c|c|c|c|c|}
\hline Parameter & PGT & PGT ointment & PGT cream & PGT gel & PGT physiowax \\
\hline Color & Greenish brown & $\begin{array}{l}\text { Brownish, and } \\
\text { brownish cream }\end{array}$ & Creamish brown & $\begin{array}{l}\text { Brownish, and brownish } \\
\text { cream }\end{array}$ & Yellowish brown \\
\hline Odor & Characteristic aromatic & Characteristic aromatic & Characteristic aromatic & Characteristic aromatic & $\begin{array}{l}\text { Characteristic } \\
\text { aromatic }\end{array}$ \\
\hline Touch & Greasy & Greasy & Greasy & Greasy & Greasy \\
\hline Consistency & $\begin{array}{l}\text { Soft, smooth, } \\
\text { homogeneous }\end{array}$ & $\begin{array}{l}\text { Soft, smooth, } \\
\text { homogeneous }\end{array}$ & $\begin{array}{l}\text { Soft, smooth, } \\
\text { homogeneous }\end{array}$ & $\begin{array}{l}\text { Soft, smooth, } \\
\text { homogeneous }\end{array}$ & $\begin{array}{l}\text { Soft, smooth, } \\
\text { homogeneous }\end{array}$ \\
\hline
\end{tabular}


Table 4: Physicochemical analysis of PGT

\begin{tabular}{|c|c|c|c|c|c|}
\hline S. No. & Parameters & Standard (API) & $1^{\text {st }}$ sample & $2^{\text {nd }}$ sample & $3^{\text {rd }}$ sample \\
\hline 1. & $\mathrm{RI}$ at $40^{\circ} \mathrm{C}$ (Abbe refractometer) & $1.4703-1.503$ & 1.481 & 1.482 & 1.481 \\
\hline 2. & Specific gravity at $40^{\circ} \mathrm{C}$ & $0.9106-0.9259$ & 0.9118 & 0.9177 & 0.9208 \\
\hline 3. & Saponification value & $160-184$ & 151.46 & 163.15 & 164.08 \\
\hline 4. & Iodine value & $104-107$ & 103.80 & 104.37 & 106.13 \\
\hline 5. & Acid value & NMT 2 & 2.0 & 2.02 & 2.0 \\
\hline 6. & Peroxide value & NMT 6 & 6.1 & 5.89 & 5.57 \\
\hline 7. & Moisture content (Karl Fischer) (\%) & - & 1.25 & 1.25 & 1.25 \\
\hline 9. & Mineral oil test & Absent & Absent & Absent & Absent \\
\hline 10. & $\mathrm{pH}$ (digital pH meter) & - & 3.75 & 3.75 & 3.75 \\
\hline
\end{tabular}

PGT: Panchaguna taila

Table 5: Phytochemical identification of PGT (Taila ointment, gel, cream, and physiowax)

\begin{tabular}{|c|c|c|c|c|c|c|c|}
\hline S. No. & Active constituent & Chemical test & PGT & PGT ointment & PGT gel & PGT cream & PGT physiowax \\
\hline \multirow[t]{4}{*}{1} & Alkaloid & Mayer's reagent & + & + & + & + & + \\
\hline & & Wagner's reagent & + & + & + & + & + \\
\hline & & Hager's reagent & + & + & + & + & + \\
\hline & & Dragendorff's reagent & + & + & + & + & + \\
\hline \multirow[t]{2}{*}{2} & Tannin & Ferric chloride test $\left(\mathrm{FeCl}_{3}\right)$ & + & + & + & + & + \\
\hline & & Lead acetate test & + & + & + & + & + \\
\hline 3 & Sterol & For digitoxose & + & + & + & + & + \\
\hline 5 & Glycoside & Borntrager's test & + & + & + & + & + \\
\hline 6 & Fixed oil & Spot test & + & + & + & + & + \\
\hline 7 & Steroids & Liebermann Burchard's test & + & + & + & + & + \\
\hline \multirow[t]{2}{*}{8} & Triterpenoids and phytosterol & Liebermann Burchard's test & + & + & + & + & + \\
\hline & & Salkowski test & + & + & + & + & + \\
\hline 9 & Amino acid and proteins & Ninhydrin reagent & - & - & - & - & - \\
\hline 10 & Carbohydrates & Benedict's reagent & - & - & - & - & - \\
\hline 11 & Saponin & Foam test & - & - & - & - & - \\
\hline
\end{tabular}

Table 6: Physicochemical analysis of PGT (ointment, gel, cream, and physiowax)

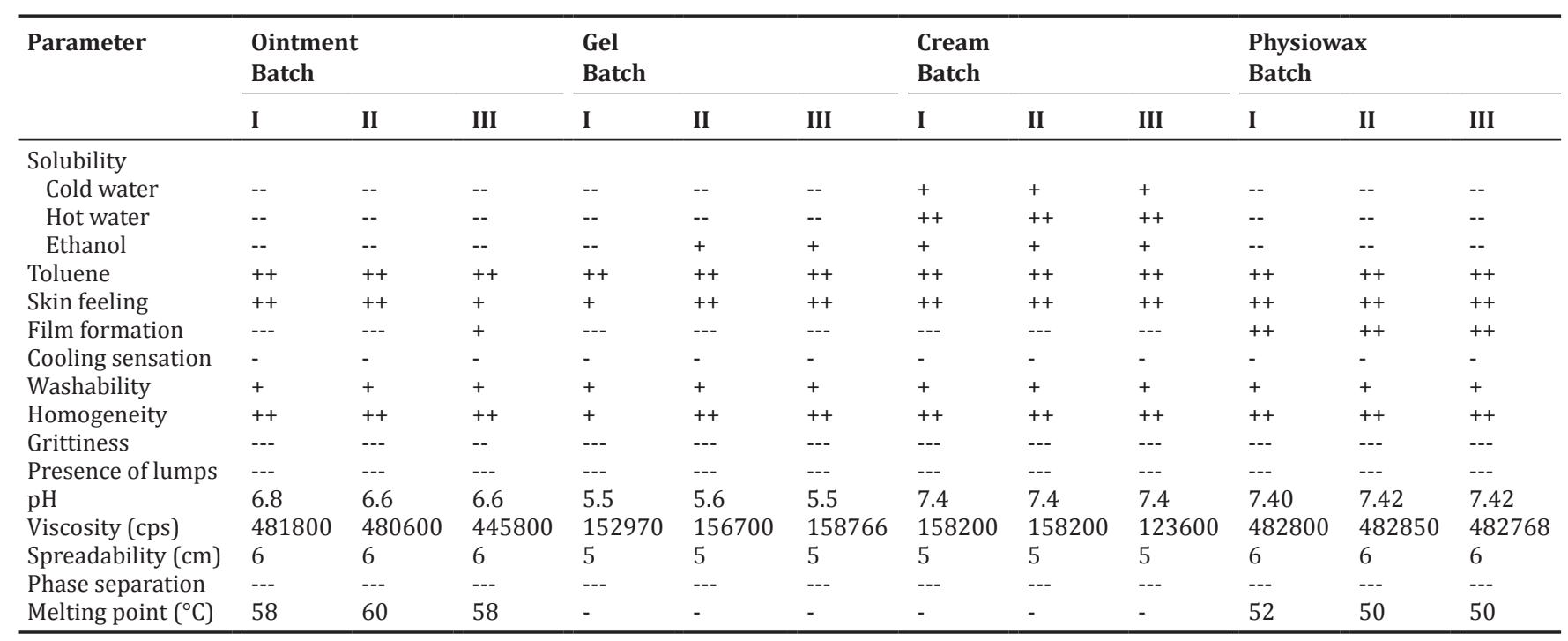

-: Not found, --: Not soluble, ---: Not present, +: Good, ++: Very good

- $\quad$ Stationary phase - Silica gel G.

- Spraying reagent - Liebermann Burchard's reagent.

- Visualization - Under visible light and ultraviolet light (at $254 \mathrm{~nm}$ ).

\section{Observation}

The thin layer chromatography study of PGT and its dosage forms were performed and the Rf observed in between the range of 0.21 to 0.84 as given in the standard monograph. In PGT, PGT ointment and PGT physiowax 10 spots were found, and in PGT gel and PGT cream 7 spots were found. $0.11,0.15$, and 0.34 spots were found in the PGT gel, PGT cream, and PGT physiowax, respectively, that can be given by the excipients or base used for their preparation.

\section{Methods}

Stability study was performed by keeping the prepared samples at accelerated temperature conditions. Nine samples of the polyherbal medicated oil (PGT) were taken in an amber-colored glass bottle and kept it at accelerated temperature of $4^{\circ} \mathrm{C}$ and room temperature of 
$47^{\circ} \mathrm{C}$. The samples were tested for the physicochemical properties like color, odor, $\mathrm{pH}$, specific gravity, etc., at the interval of 24,48 , and $72 \mathrm{hrs}$ to observing the changes.

\section{RESULTS}

The present work formulation and evaluation of PGT and its conventional dosage forms were aimed to formulate dosage form using PGT as base

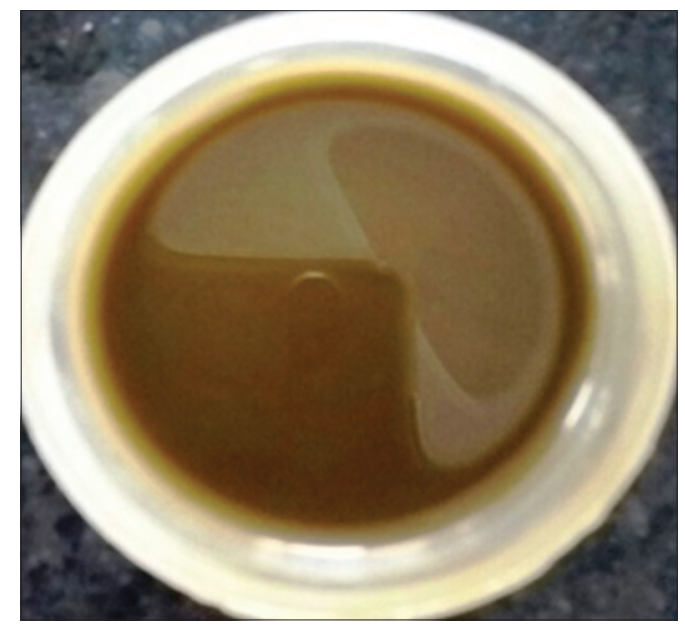

Fig. 1: Panchaguna taila

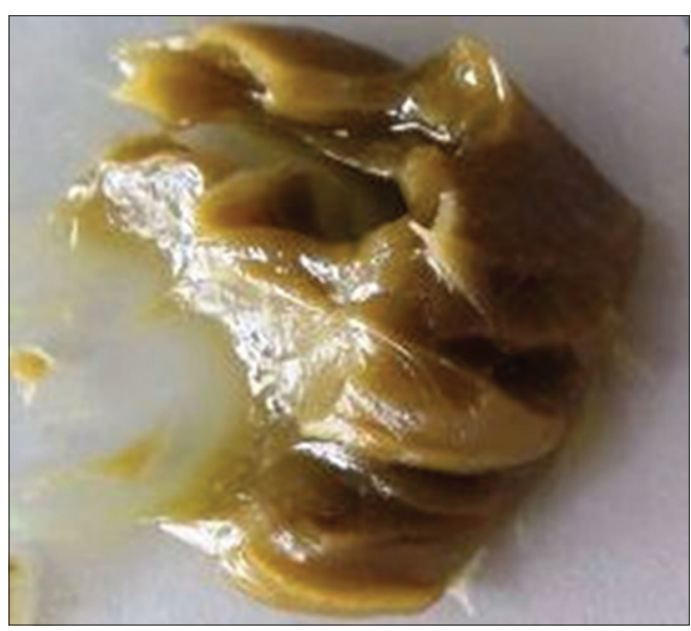

Fig. 2: Panchaguna taila ointment

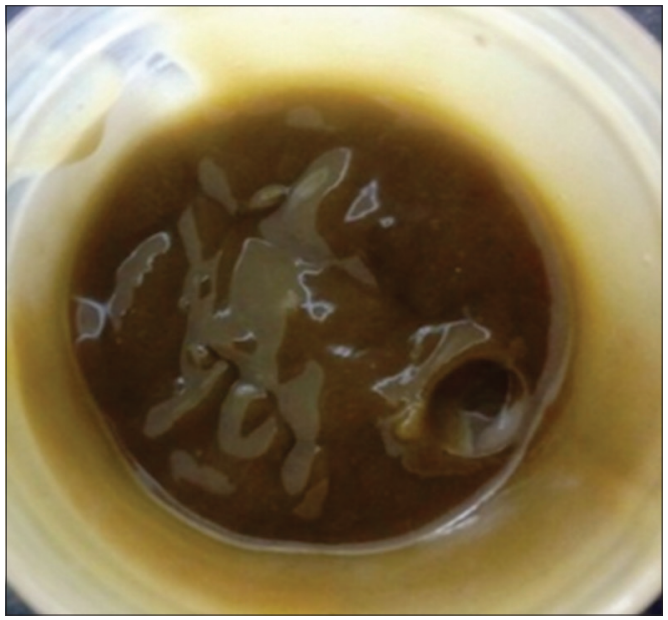

Fig. 3: Panchaguna taila gel (active pharmaceutical ingredient [API]) with a hope to minimize the inconveniences and to increase the customer acceptability and compliance of PGT. Final quantity obtained of processed PGT and its dosage forms are cited in Tables 2 and 3 and in Figs. 1-5. Macroscopic or organoleptic study of all the prepared formulations is performed, and they comply with the some of the characters with the PGT as shown in Table 4. All the samples of PGT were subjected to the various physicochemical parameters, and all the values comply with the official monograph value. Physicochemical

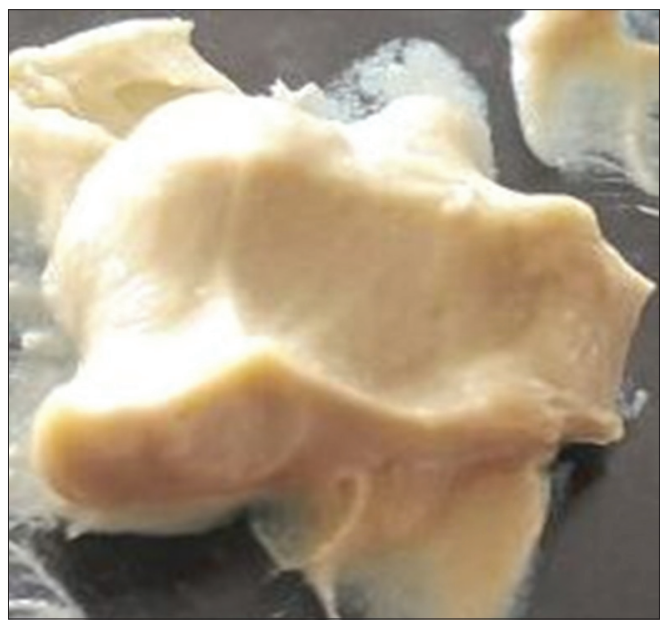

Fig. 4: Panchaguna taila cream

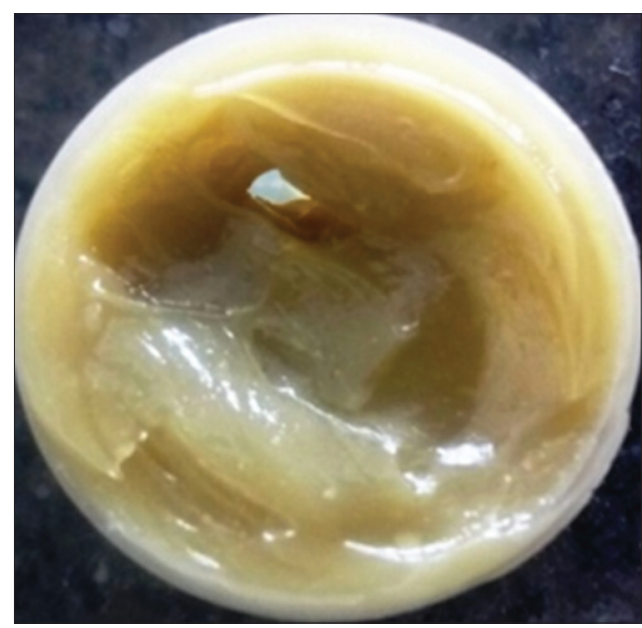

Fig. 5: Panchaguna taila physiowax

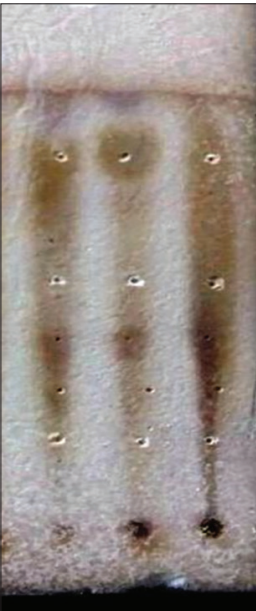

Fig. 6: Panchaguna taila and dosage forms (visible light) 
analysis of PGT ointment, PGT gel, and PGT physiowax was performed and all show good results as cited in Tables 6. The PGT, PGT ointment, and PGT gel TLC study shows spots at $\mathrm{R}_{\mathrm{f}} 0.21,0.27,0.38,0.42,0.71,0.81$, and 0.84 and cited in Figs. 6 and 7. Spreadability $(\mathrm{cm})$ of prepared dosage forms was performed. PGT ointment and PGT physiowax show $6 \mathrm{~cm}$, and PGT gel and PGT cream show $5 \mathrm{~cm}$ spreadability as given in the Figs. 8-11. Phytochemical screening of PGT and its dosage forms was performed,

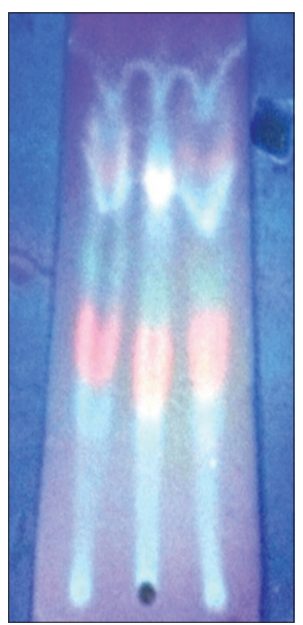

Fig. 7: Panchaguna taila and dosage forms (ultraviolet light at $254 \mathrm{~nm}$ )

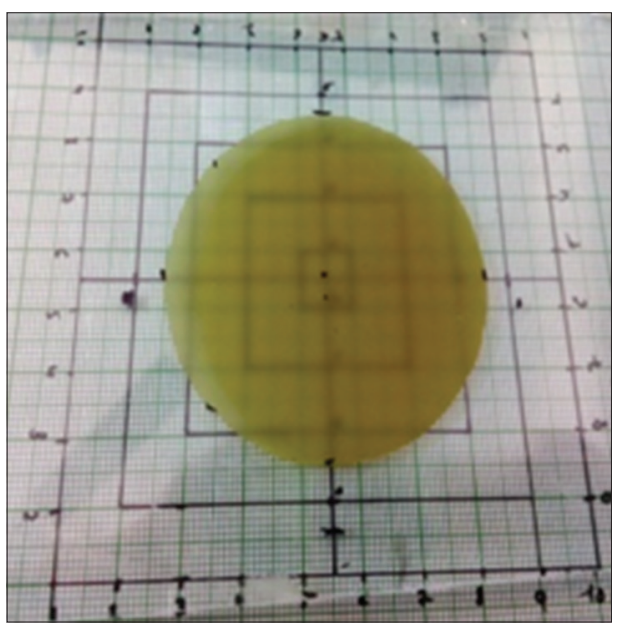

Fig. 8: Spreadability of ointment

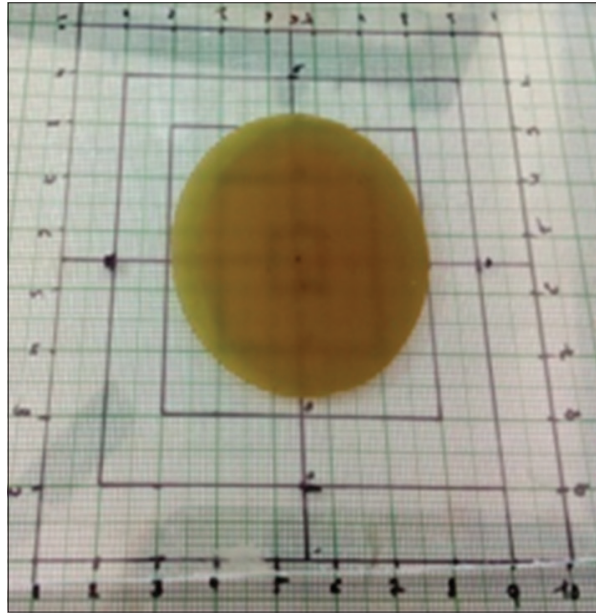

Fig. 9: Spreadability of gel and all they show positive results for the various phytochemical constituents as given in Table 5. Stability study of PGT performed at accelerated conditions by keeping samples of prepared dosage forms for 3 days. During the stability study, various physicochemical parameters were performed within the specific interval of time. After the comparison between the observed values, there was no significant variation found as cited in Table 7.

\section{DISCUSSION}

PGT was prepared by classical principles of Ayurveda and converted into ointment, gel, cream, and physiowax. Precautions were taken during the processing of PGT and the temperature was never exceeded $70^{\circ} \mathrm{C}$ while preparing ointment, cream, and physiowax. Spreadability of ointment and physiowax was relatively higher than cream and gel (Figs. 8-11). Melting point of physiowax was less than ointment. TLC was performed for PGT, PGT ointment, and PGT cream, and the $\mathrm{R}_{\mathrm{f}}$ values were observed in the range of 0.21-0.84. Pharmacognostic, physicochemical, and phytochemical study of formulations was studied, and it showed that all the chemical compounds that were in the prepared oil were also present in the other developed dosage forms. Stability study of PGT was done for 3 days. During the stability study, the various physicochemical studies were done within the specific interval of time of 24,48 , and 72 hrs. The results obtained during the stability study were compared, and no significant variation was found in the results.

\section{CONCLUSION}

PGT is polyherbal medicated oil used externally for treating wounds, cut, and burns and used for massaging in rheumatoid arthritis, muscular

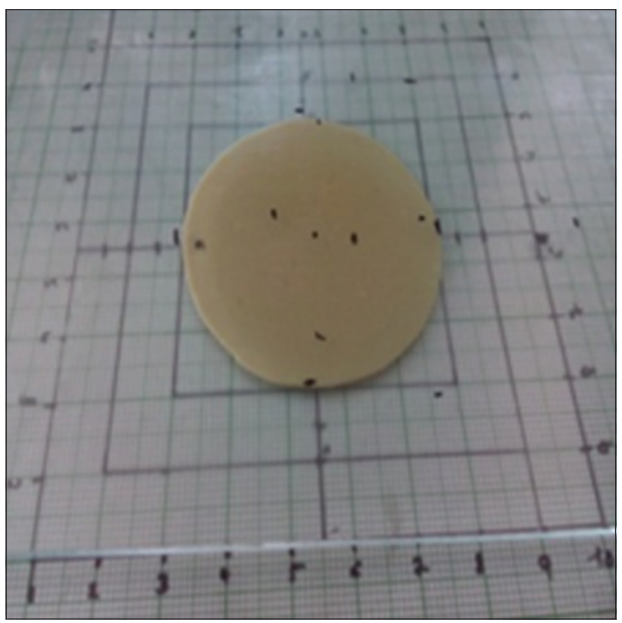

Fig. 10: Spreadability of cream

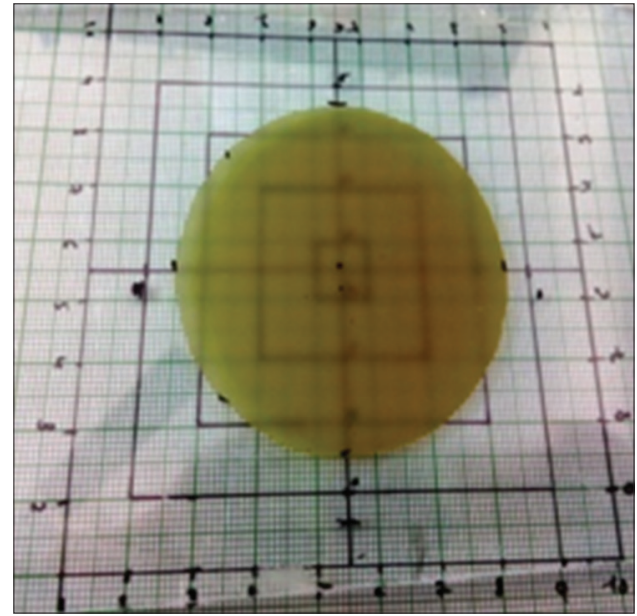

Fig. 11: Spreadability of physiowax 
Table 7: Stability study of Panchaguna taila was done for the duration of 3 days at accelerated temperature conditions [15]

\begin{tabular}{|c|c|c|c|c|c|c|c|c|}
\hline \multirow[t]{2}{*}{ Sample } & \multirow{2}{*}{$\begin{array}{l}\text { Time duration in } \\
\text { hour }\end{array}$} & \multirow[t]{2}{*}{ Temperature ${ }^{\circ} \mathrm{C}$} & \multicolumn{6}{|c|}{ Physiochemical parameters } \\
\hline & & & Color & Odor & Form & pH & $\mathrm{Wt} / \mathrm{ml}$ at $25^{\circ} \mathrm{C}$ & Specific gravity at $40^{\circ} \mathrm{C}$ \\
\hline $1 \mathrm{~A}$ & 24 & $4^{\circ} \mathrm{C}$ & NC & $\mathrm{NC}$ & Viscous & 3.75 & $1.094 \mathrm{~g}$ & $0.9175 \mathrm{~g} / \mathrm{ml}$ \\
\hline $1 \mathrm{C}$ & & $47^{\circ} \mathrm{C}$ & NC & $\mathrm{NC}$ & Less viscous & 3.75 & $1.094 \mathrm{~g}$ & $0.9177 \mathrm{~g} / \mathrm{ml}$ \\
\hline $2 \mathrm{~A}$ & 48 & $4^{\circ} \mathrm{C}$ & NC & $\mathrm{NC}$ & Viscous & 3.75 & $1.094 \mathrm{~g}$ & $0.9175 \mathrm{~g} / \mathrm{ml}$ \\
\hline $2 \mathrm{~B}$ & & Room temperature & NC & NC & $\mathrm{NC}$ & 3.75 & $1.094 \mathrm{~g}$ & $0.9177 \mathrm{~g} / \mathrm{ml}$ \\
\hline $2 \mathrm{C}$ & & $47^{\circ} \mathrm{C}$ & NC & $\mathrm{NC}$ & Less viscous & 3.75 & $1.094 \mathrm{~g}$ & $0.9177 \mathrm{~g} / \mathrm{ml}$ \\
\hline $3 \mathrm{~A}$ & 72 & $4^{\circ} \mathrm{C}$ & NC & $\mathrm{NC}$ & Viscous & 3.75 & $1.094 \mathrm{~g}$ & $0.9175 \mathrm{~g} / \mathrm{ml}$ \\
\hline $3 \mathrm{~B}$ & & Room temperature & NC & $\mathrm{NC}$ & $\mathrm{NC}$ & 3.75 & $1.094 \mathrm{~g}$ & $0.9177 \mathrm{~g} / \mathrm{ml}$ \\
\hline $3 \mathrm{C}$ & & $47^{\circ} \mathrm{C}$ & NC & NC & Less viscous & 3.75 & $1.094 \mathrm{~g}$ & $0.9177 \mathrm{~g} / \mathrm{ml}$ \\
\hline
\end{tabular}

NC: No change

pain, sprains, and joint pains. Using standard PGT as active API, various dosage forms were prepared such as PGT ointment, PGT gel, PGT cream, and PGT physiowax. PGT is greenish brown in color and other dosage forms are brownish and cream in color with characteristic aromatic odor. Analytical standards for PGT such as acid value, saponification value, iodine value, and peroxide value were performed, and obtained results were respectively under the prescribed limit in official monograph. Various physicochemical parameters such as homogeneity, spreadability, $\mathrm{pH}$, and melting point were performed for PGT ointment, PGT gel, PGT cream, and PGT physiowax. Stability study of PGT was done for 3 days under the accelerated conditions. During the stability study of PGT, various physicochemical parameters were performed on the interval of 24, 48, and $72 \mathrm{hrs,}$, and no significant variation found in their physicochemical properties when observed values were compared. PGT ointment, PGT gel, PGT cream, and PGT physiowax containing PGT as active API with various suitable excipients and base are easy to formulate and convenient to apply over the affected area. Exact references for the PGT ointment, PGT gel, PGT cream, and PGT physiowax are not reported earlier, and on trial and error basis, various dosage form was developed. As these, conventional prepared dosage forms non-irritant and possess good spreadability can be replaced the classical oil forms. The prepared dosage form also has elegancy that other bases lack an important aspect from patient compliances and customer satisfaction. The wider therapeutic potential of such dosage forms may motivate the researchers for further exploitation of their commercial feasibility.

\section{ACKNOWLEDGMENT}

The authors are grateful to Lovely Professional University, Phagwara, for providing the necessary infrastructure and resources to carry out this research project.

\section{REFERENCES}

1. Sharanagadhara Samhita with "Dipika Hindi Commentary". Vol. Ch. 9. Edited by Brahmanand Tripathi. Varanasi: Chaukhamba Subharti Prakashan, Madhyam Khand; 2008.

2. Anonymous. The Ayurvedic Pharmacopoeia of India, Part I. Vol. I.
New Delhi: Government of India, Ministry of Health and Family Welfare, Department of Ayush; 2001. p. 62, 63.

3. Chavan PS, Bhoyar M, Khiyani RM. A critical study on guggulu (Commiphora mukul) - A review. Int J Ayrveda Altern Med 2015;3(3):159-66.

4. Pimpale S, Rao A, Patil A, Desai S. Comparative analytical study of guggulu (Commiphora mukul) Shodhana done in different media. Int Ayurvedic Med J 2014;2(5):2320-5091.

5. Shastri A. Bhaishajya Ratnavali. Varanasi: Chaukhamba Samskarta Samsthana; 2002.

6. Caster SJ. Cooper and Gunn's Dispensing for Pharmaceutical Studies: Ointments, Pastes, Jellies. $12^{\text {th }}$ ed. India: CBS Publisher \& Distributors; 1987. p. 192-210.

7. Sharma PP. Cosmetics for skin. Cosmetics Formulation Manufacturing \& Quality Control, Part II. Ch. 7. New Delhi: Vandana Publication; 1998. p. 181

8. Troy DB, Beringer P. Remington: The Science and Practice of Pharmacy. $21^{\text {st }}$ ed. New Delhi: .2015.

9. Ravindra J, Pratibha RP, Patil PH. Formulation and evaluation of semisolid preparation (ointment, gel \& cream) of thiocolchicoside. J Pharm Biomed Sci 2011;8(1):2230-7885.

10. Goriya P, Dhawani HS, Galib R, Shukla VJ, Prajapati PK. Formulation development and preliminary physicochemical characterization of Kustha taila. Int J Res Ayurveda Pharm 2014;5(3):246-51.

11. Khandelwal KR. Practical Pharmacognosy Techniques and Experiments. 12 $2^{\text {th }}$ ed. Pune, India: Nirali Prakashan; 2004.

12. Saklani S, Mishra AP, Sati B, Sati H. Pharamcognostic, phytochemical and antimicrobial screening of Alphanamitis polystachya \& endangered medicinal trace. Int J Pharm Pharm Sci 2012;3:975-1491.

13. Anonymous. Protocol for testing Ayurveda, Siddha and Unani Medicines. Ghaziabad: Government of India, Ministry of Health and Family Welfare, Department of AYUSH, PLIM; 2006.

14. Kumar SP, Prasan ND. Development of evaluation of polyherbal syrup from same herbs used as expectorant. World J Pharm Pharm Sci 2013;2(5):3848-53.

15. Mehta NJ, Patadiya ND, Patel J, Shastri DH, Shelet PK. Development and evaluation of a anti-arthritic herbal ointment. Res J Pharm Biol Chem Sci 2013;1(4):975-8585.

16. Anonymous. The Ayurvedic Formulary of India, Part II. Vol. III. New Delhi: Government of India, Ministry of Health and Family Welfare, Department of Ayush; 2010. 